\title{
Multiple Mediations in Zora Neale Hurston's Mules and Men
}

\section{Graciela Hernández}

University of Michigan

Mules and Men (1935) is a precedent-setting study of folklore in the African-American communities of Eatonville and Polk County, Florida and New Orleans, Louisiana, in which Zora Neale Hurston attempts to represent her fieldwork experiences in writing. In this work, Hurston uniquely records a variety of slave tales, songs and conversations by interspersing these cultural forms with the ethnographic narrative. My discussion, which is confined to Hurston's ventures in Florida, centers on Hurston's acts of mediation as she negotiates a number of tensions. The tensions that Hurston negotiates stem in part from her self-positioning as a 'native ethnographer' and from her refusal to cast off the analytical tools of her trade. Hurston self-consciously cultivates the authoritative divide based upon objective and authentic stances by weaving together narrative voices that yield multi-dimensional interpretations of her experiences. ${ }^{1}$ This mode of expression, so aware of academic privilege, dominates the first part of the ethnography, but it gives way later in the text to a stunning critique of the position that she assumes in the field. The strength of Hurston's work, I argue, lies in her ability to turn the anthropological venture on its head and to suggest when the limitations of knowing an 'Other' are exceeded or foreclosed.

While I am primarily concerned with interpretations of Zora Neale Hurston's project, I also hope to explore the implications of using blurred genres and literary strategies in narratives of fieldwork. What theoretical insights do such techniques reveal? I also want to suggest that Hurston is not a solitary figure in a struggle to represent cultural exchange and interaction. For example, it seems important to draw comparisons between Hurston and other 'native ethnographers' of her era, such as Native American ethnographer Ella Deloria. ${ }^{2}$ What issues and strategies serve to intersect or divide the body of scholarship published by these women? As my study of Hurston suggests, recognizing the subversive

Critique of Anthropology (C) 1993 (SAGE, London, Newbury Park and New Delhi), Vol. 13(4): 351-362. 
moments that inhere in the work of women and 'native ethnographers' provides new theoretical possibilities for understanding the relationship between both informants and ethnographers, while also profoundly challenging the basis of anthropological knowledge.

Before beginning an exploration of Mules and Men, one must place Hurston both in the intellectual milieu of the early twentieth century, as well as assess the socio-political moment in which her narrative and life are embedded. While I take as my central concern Hurston's attempt to resolve the Self/Other divide through a process of epistemological erosion, other tensions affected her intellectual development and her writing as well. I provide the context for Hurston's work to suggest that a multiplicity of demands were placed upon her, forcing her to mediate tensions beyond those produced in a fieldwork situation.

Zora Neale Hurston was part of the intellectual and artistic movements of the Harlem Renaissance, the new theoretical strains in anthropology, and the legacy of a quickly disappearing 'amateur' anthropology (Gordon, 1990; Mikell, 1983, 1989). As a young woman living in Washington DC and attending Howard University between the years 1918-1924, Hurston was influenced by the thinking of Renaissance scholars, such as Alain Locke, who sought to articulate the 'aesthetic experience' of black culture (Gordon, 1990: 160). He envisioned texts as instrumental in the creation of African-American 'high culture' that in turn could be widely disseminated and used to increase African-Americans' understanding of themselves (Gordon, 1990: 161). Locke's influence on Hurston's development as a writer undoubtedly affected her early literary attempts and thought process, although Hurston's biographer, Robert Hemenway, points to Hurston's and other young Renaissance artists' resistance to Locke's philosophy of art and representation (Hemenway, 1977).

Perhaps just as important was Locke's role in introducing Hurston to Mrs Rufus Osgood Mason, a white woman who remained Hurston's 'patron' from 1927-1933. Mason's distribution and control of material resources that supported African-American scholarly and artistic activities necessarily influenced these scholarly and artistic products. In Hurston's case, Mason's training as an 'old school ethnographer' prompted her to emphasize the collection and presentation of folklore as the 'laying out of objects as if in an art museum' (Gordon, 1990: 160). Robert Hemenway's nuanced study of the relationship between Hurston and her patrons points to conflicts experienced between Hurston and Mason. Hemenway argues that the patronage relationship drew Hurston away from her own desire to write fiction, yet 'force[d] her to define the role of black folklore, in her life and in her fiction, much more clearly . . .' (1990: 36). 
The paradigm introduced by Mason was clearly at odds with the theory and methodology taught by Franz Boas at Barnard College and Columbia University (Gordon, 1990; Mikell, 1983). Boas, as Hurston's third intellectual mentor, stressed the need to expound upon wider cultural implications. Under Boas's leadership, American anthropologists moved away from evolutionary and diffusionist models developed in the late nineteenth century and toward models of cultural relativism (Mikell, 1983: 29). In contrast to Mason's model, the Boasian model did not allow one to simply 'display' individual stories and folk tales; one needed to situate those tales within an explanation of their meaning (Gordon, 1990: $160)$. It is within the context of competing theory and methodology that I would like to locate my discussion of Hurston's ethnography, Mules and Men.

In the Introduction to Mules and Men, Hurston immediately establishes a framework of two intertwining voices: the voice of the ethnographer and the voice of the community member. In this section, Hurston establishes her position vis-a-vis anthropology and ethnography in two ways. First, Hurston tells the reader that the discipline of anthropology gave her the 'spy-glass' that she needed in order to 'stand off and look at my garment' $(1935 / 1990: 1)$. The reference to the spy-glass is an assertion that her account will be a distanced view of herself and the community she will study. Through the use of this image, Hurston attempts to establish credibility - though with irony - as one who is able to distance herself from African-American culture, despite her inherent interest and entrenchment in the community.

Hurston's claim to such methodology and hence to objectivity is only one dimension of the construction of a scholarly persona. Claiming anthropological method as a useful tool with which to evaluate her culture also serves to instill Hurston with a certain amount of authority. Hurston will not simply be listening to and recording folkloric accounts in a haphazard manner. Instead, she implies that these accounts will be systematically obtained and translated within a theoretical framework. By invoking the theory and methodology of an academic discipline, Hurston imbues herself with a set of credentials that legitimize her final written product.

Before I continue the discussion of Hurston's self-construction in the text, I want to return briefly to the image of the spy-glass, which is a revealing image that bears critical discussion because of the far-reaching implications both for anthropology as a discipline and ethnography as a practice. This 'spy-glass' serves not only as an image that neatly positions Hurston as the objective observer, but as an instrument with the theoretical and literal potential to inflict violence upon the observed. It is remarkable 
to me that this passage, where Hurston professes the ability to stand outside of the African-American community, is widely quoted in scholarly accounts of Hurston's work. In most contexts that I have read, scholars interpret the garment-spy-glass link as the innocuous blooming of Hurston's scholarly self-confidence. In very few instances do scholars explicitly recognize how the spy-glass works to render that which is far from view into sharp and static focus. Furthermore, once that view becomes apprehensible those subjects become objects and become Others. Because of her spy-glass, Hurston, like other ethnographers with glasses in hand, has the potential power to define and fix meaning, to rarefy the complexity of the lives around her, and to occupy space in the field as a colonizer.

Lila Abu-Lughod, in her discussion of the awkward relationship between anthropology and feminism, quite succinctly delineates the two aspects in which anthropology is implicated in a colonial project. She states that anthropology 'is a discipline built on the historically constructed divide between the West and the non-West. . . . And the relationship between the West and the non-West ... has been constituted by Western domination' (Abu-Lughod, 1991: 139). Although Hurston worked within a Western context by virtue of having studied communities in the United States, this did not exempt her projects from such power dynamics. The divide that separates the West from the non-West is often replicated within the United States between the dominant society and 'minority' communities. As scholars question the relationship between colonial configurations of power and their enquiry abroad, so they must also bring their interrogations 'home'.

I stress that Hurston's power to assume a colonial position is a potential power because, even as she delivers this tightly defined account of herself as an objective ethnographer, she simultaneously presents herself as a member of an African-American community that has the amazing ability to contest hierarchical relationships. Hurston begins, in the introduction of Mules and Men, by saying that collecting 'Negro' folklore 'would not be a new experience for me. When I pitched headforemost into the world I landed in the crib of negroism' (1935/1990:1). Hurston asserts her membership in the community and then speaks to the issues of cultural authenticity and authority. Hurston assures her reader that she is of the 'Other's' world and identifies herself as an 'insider'. On the second page of the introduction, Hurston claims that no amount of education will ever separate her from her people. If indeed she were to attempt superiority over her people, then they would quickly remind her that she would 'still be just Zora' (1935/1990: 2). By revealing this information, Hurston acknowledges that her community exercises the tremendous power of naming her 
as simply 'Zora', thus leveling the power differentials. Hurston proceeds to reassure her audience that her collection is not 'contaminated' with information designed to make the 'outsider anthropologist' seem foolish; her folk tales are as authentic as she herself is.

The framework that Hurston constructs for the audience is such that she attributes to herself the objectivity and authority of an anthropologist and the authenticity and authority of a community member. In a sense, Hurston alerts her reader to a type of code-switching that will occur as she mediates between two constructions: the authoritative 'outsider' anthropologist and the authoritative 'insider' community member, showing that the two are not mutually exclusive. The construct that Hurston works so hard to achieve in the first few pages prepares us for an ethnography that embraces - in an unusual way - the participant-observer paradigm that was encouraged by her mentor Franz Boas (Mikell,1983).

This oscillation between an anthropologist's position and a community position is readily seen in the first few exchanges between Hurston and her informants and is most consistently sustained throughout the first eight chapters of the text. In Chapter One, as Hurston pulls her car into Eatonville, she states, 'I hailed them [the townsmen] as I went into neutral' (1935/1990: 7, my emphasis). While it is the car that moves into neutral, Hurston herself may be indicating a symbolic neutrality between her identities as an anthropologist and as a community member. By neutralizing this rivalry between her positions, she begins the complex negotiation between identities in which no voice is continually privileged over another.

One example in which the two voices intertwine is found in the initial interaction between Hurston and the group of townsmen seated on the store-porch. Hurston begins by responding to questions in black English vernacular, declaring that she has come to collect folklore, or 'lies' as the men call them. Answering their incredulous response about why she would want to do that, Hurston replies, 'We want to set them down before it's too late' (1935/1990: 8, my emphasis). In these passages, Hurston competes for acceptance in both the African-American community and the academic community. She uses black English vernacular to assert her inclusion as an African-American woman, while the reference to 'we' specifies that she sees herself as an anthropologist working in conjunction with other anthropologists. During the first eight chapters of Mules and Men, neither the identity as ethnographer nor her identity as African-American woman prevails.

From the tension between the anthropologist's voice and the community voice an overtone, or a literary harmonic, emerges during the first half of Part I. The existence of this literary overtone perhaps testifies to the 
difficulty Hurston may have felt in maintaining a balancing act between the identities she constructs as Hurston the ethnographer and Hurston the African-American woman. In attributing to herself anthropological authority, Hurston realized that her ethnographic account has to engage in explicit critique and explication. Yet broad generalizations are noticeably absent from Mules and Men. On the other hand, as a member of the African-American community, Hurston is expected to respect the sanctity of that community, a fact which may account for her inability or unwillingness to explain the meaning folklore has in the lives of her Eatonville friends. In her article 'The Anthropological Imagination of Zora Neale Hurston', Gwendolyn Mikell, who has written about Hurston's work as an ethnographer, identifies Hurston's 'inherent conflict' as 'an identification with the people she studies, and a willingness to participate in their reality, as well as an intellectual separation from them and a reluctant pronunciation of judgment and characterization' (1983: 30). According to Mikell, Hurston seeks to more assertively resolve this conflict, however unevenly, in Tell My Horse. In her research undertaken in Jamaica and Haiti, Hurston assumes a more explicitly analytic stance toward Caribbean culture. However, before the Caribbean venture, Hurston sought to resolve this inherent conflict in her ethnographic work by employing textual innovations instead. ${ }^{3}$ One of the chapters that most strongly holds up to a close literary reading, thus testifying to Hurston's imaginative response in maintaining the integrity of her professional identity and her personal identity, is Chapter Two. By 'literary reading' I mean to suggest that instead of providing an explicit critique on Eatonville and Polk County culture, Hurston provides 'red flags' for the readers to find and interpret, as do many fiction writers and poets. Hurston hints that readers must find their own meaning in her text when her character Larkins says the following about 'them kinda by-words':

They all got a hidden meanin', just like de Bible. Everybody can't understand what they mean. Most people is thin-brained. They's born wid they feet under de moon. Some folks is born wid they feet on de sun and they kin seek out de inside meanin' of words. (1935/1990: 125)

Hurston mockingly refers to herself in this passage, while also issuing a challenge to her readers to search carefully among her words and structures to understand the implicit critique of the community life that she documents.

Hurston seems to be using the voice of a fiction writer in this chapter, carefully constructing the placement of the dialogue, folklore stories and conflicts. For example, Chapter Two is primarily concerned with Eatonville informants' responses to preachers, churches and God. Hurston first 
records two stories about preachers, one of whom reaps the financial rewards of his position and another who uses frightening and intimidating means to convert people. The third 'lie' presented by Hurston is the story of the broken foundations of the Christian Church in which the informants testify to the impossibility of religious unity. In between the tales of the preachers and the tale of the church foundation, Hurston inserts a long prayer praising God that she claims to have overheard in one of the town churches. While allowing her reader glimpses into the cynicism some members of Eatonville express toward religion and religious institutions, Hurston complicates our understanding of Eatonville by juxtaposing cynical views against expressions of faith and commitment to God. She covertly provides a multi-dimensional sketch of religion in Eatonville, from which readers begin to draw tentative conclusions about the varying opinions and interpretations of religion within one community. Hurston thereby maintains her loyalty to her anthropological voice and also remains accountable to her community voice by constructing an implicit analysis of the community.

Similarly, we can view Chapter Five as another example of how a constructed situation yields a powerful critique. In this chapter Hurston presents ten slave stories, beginning with accounts of slaves tricking one another. The accounts then move from situations whereby slaves fool either their masters or God, to situations that culminate with slaves winning their freedom. Hurston moves from lighthearted, funny tales to hopeful tales and tales affirming freedom. This very self-conscious ordering of the tales leads me to conclude that slave tales are told as a way of extending into the present past efforts of resistance to oppression and violence. In this way, what can be seen as the benign, apolitical or voyeuristic presentation of folk tales is instead a powerful validation of the Eatonville African-American community's struggle for affirmation and survival.

Despite the successful deployment of textual innovation, the tension between the position of the ethnographer and the position of the African-American 'Other' is not consistently maintained throughout Mules and Men. Hurston begins to express these voices in varying degrees, and eventually abandons the anthropological persona, as she narrates her movement from Eatonville to Polk County, Florida. The movement into Polk County, then, complicates the tension between the emic and etic that characterizes the first eight chapters. With the movement to Polk County, Hurston not only has to reestablish the credibility of her position as an insider to the audience, but she has to represent herself as an insider to a community that is unfamiliar with her. 
The problems with narrative voice begin when Hurston is rejected by the Polk County community. When Hurston presents herself to her new informants she is looked upon with suspicion because of her relatively high socio-economic standing. Hurston curses the fact that she is wearing a $\$ 12.74$ dress purchased at Macy's, while all the other townswomen are wearing $\$ 1.98$ dresses purchased by mail order. In order to overcome this barrier Hurston lies to the community and tells them she is a bootlegger's woman. At this point she presents herself only as an 'insider' rather than as an anthropologist, momentarily halting the tension between her two identities. She later explains that she 'got confidential and told them all what $I$ wanted' (Hurston, 1935/1990: 65, my emphasis). This sentence, with its emphasis on the ethnographer as an individual, directly contrasts the inclusive 'we' first used when the narrator arrived in Eatonville. This individual emphasis seems to indicate that Hurston distances herself from her own ethnographic voice and accompanying anthropological community in order to reinforce acceptance among her informants.

In addition, it is interesting to note that Hurston never elaborates upon the exact nature of her disclosure to the Polk County residents. How much does Hurston tell the Polk County residents? Does Hurston tell them she is associated with Barnard College and Columbia University, a well-known fact in Eatonville? Or does Hurston simply tell the community members that she wants to write down folk tales? Immediately, we notice that a new power differential is introduced in this field situation, because the community cannot name her, as could the Eatonville community, since what they know of her is based upon a lie. They do not have the power to dismantle the hierarchies inherent within the participant-observer paradigm. The silences and elisions in Hurston's ethnographic voice may help to explain the violence Hurston later encounters while she is in Polk County, and that I will discuss shortly.

As Hurston abandons her ethnographic voice and relies increasingly on her personal voice when interacting with Polk County residents, she may be undergoing a process similar to the one described by scholar Dorinne K. Kondo. Kondo speaks of the pressure she felt to 'reduce the distance between Self and Other' while she undertook fieldwork in Japan (1985: 77). This pressure, not merely self-motivated, for her informants reinforced the pressure and rewarded her accordingly for succumbing, continued until Kondo found that her 'collapse of identity' had become so pronounced that her self of herself as Self/Other no longer seemed unified. Acting to rectify this situation, Kondo moves into her own apartment, using the physical distance between her informants and herself to recover her sense of multiple identities. 
Zora Neale Hurston may have found herself in a similar situation in Polk County, where she gradually abandons her identification with her role as an ethnographer in order to improve the quality of her folklore collection. An examination of her narrative voices in Chapters Nine and Ten shows that Hurston's collection of folklore in Polk County has nearly come to a halt. Hurston mentions that she collects songs from her informants, but most of the information given to the reader concerns the relationship between Big Sweet and Hurston and the escalating conflict between Lucy, Ella, Big Sweet and Hurston. In the last few pages of Mules and Men, Ella and Lucy collude to kill Hurston at a dance. An in-depth quote provides a sense of the confusion and violence that characterizes Hurston's and the readers' exit from the field:

Just about that time Lucy hopped up in the doorway with an open knife in her hands. ... .

'Stop dat music,' she yelled without moving. 'Don't vip another vop till Ah say so! Ah means tuh turn dis place out right now. Ah got de law in mah mouf.'

So she started walking hippily straight at me . . . I could hear the blade already crying in my flesh. I was sick and weak. But a flash from the corner and Lucy had something else to think about besides me. Big Sweet was flying at her with an open blade and now it was Lucy's time to try to make it to the door. Big Sweet kicked her somewhere about the knees and she fell. A doubled back razor flew thru [sic] the air very close to Big Sweet's head. . . . Jim Presley punched me violently and said, 'Run you chile! Run and ride! Dis is gointer be uh nasty ditch. ....'

Slim stuck out the guitar to keep two struggling men from blocking my way. Lucy was screaming. . . . Curses, oaths, cries and the whole place was in motion. Blood was on the floor. I fell out of the door over a man lying on the steps. . . . I was in the car in a second and in high just too quick. Jim and Slim helped me throw my bags into the car and I saw the sun rising as I approached Crescent City. (178-179)

While this conclusion brilliantly captures conflict and confusion, it is a scene that cannot be read strictly as a literary text. Rather, it begs to be read as a statement on the relationship between informants and ethnographer, between text and voice, and between authority denied and authority seized. In other words, the text cannot be separated from a complex web of social relationships. One of the implications that can be suggested immediately is that in Hurston's quest to find acceptance among the Polk County residents, she had identified with the community to the extent that she could no longer record or present their folk knowledge. Another ironic point is that the community accepts Zora Neale Hurston as so much a part of itself that it tacitly sanctions the violence directed at her by Lucy; as a 
member of the community, Hurston has to deal with acts of violence as do all other members of the community.

These conclusions posit that the violence enacted against the ethnographer is of the same calibre as the violence enacted against informants when an anthropologist begins the process of observing 'others'. Yet Hurston escapes relatively unscathed, while those trapped in the dance hall experience the bloodshed and chaos precipitated by Hurston's presence. I find myself at an impasse because while I want to level a critique of ethnographic practice, I also find myself searching for ways to redeem Hurston. This leads me to attempt a reading of Hurston's subversive potential.

I propose, as does John Dorst in 'Rereading Mules and Men: Toward the Death of the Ethnographer', that Hurston portrays 'the demise of Authority' in her text $(1987: 316)$. Specifically, Hurston moves on the symbolic level in this last section of the text. As the women in the Polk County community move to kill Zora, so Hurston moves to 'kill' or to render unviable the primary paradigm within which she works in the field and represents in the text of Mules and Men. Hurston rejects the authority of an insider/outsider position, and suggests that ethnographers cannot carve spaces for themselves in societies where anthropologists define people as objects or others for view through the lenses of the spy-glass. Moving beyond the scope of what Hurston implies about her own position in the field, it is important to point out that Hurston denies the space of authority and community to her audience as well. That is, if Hurston allows her audience such latitude in the construction of meaning in her text through implicit analysis, then we too are implicated as participant/observers, or 'insider/outsiders'. We, too, have been denied power and denied community.

Rather than suggest a vacuum where space exists without power and authority, I suggest that Hurston provides compelling clues as to the movement of and location of power. In the last few paragraphs, Lucy states 'Ah got de law in mah mouf.' Lucy takes the 'law', in this case the authority and power to define meaning, away from Hurston and into her own hands, or 'mouf'. Perhaps one of the most significant consequences of Lucy's actions is her assertion of the primacy of the oral word over the written text. Hurston has gone to collect the folklore and folktales of different African-American communities to 'set them down before its too late', yet Lucy strategically moves to disrupt Hurston's unproblematic exit from the field situation with folk knowledge in hand. The epistemic privilege of the written text is debunked in favor of the oral. In the final scenes, the power to define the terms upon which an ethnographer works, records, and leaves the field lies not with the interlocutor, but with the informants. 
Zora Neale Hurston's most powerful contribution to anthropology could be her ability to allow the spy-glass to fall aside, revealing the struggle for power that takes place between the ethnographer and the subject in which both vie to define the field and the possibility of representation. Hurston leaves us, not with a focus upon a pliant object from which we can abstract a general understanding of a culture, but with a sense of the shifts, movements and conflicts that characterize our interactions in the field. Ultimately, she shows us how to write ethnography that makes the spy-glass absurdly unnecessary.

\section{ACKNOWLEDGMENTS}

I would like to thank the following mentors and colleagues for providing support, animated discussion and critical insight into my work: Ruth Behar, Rebecca L. Coste, the American Culture Brown Bag participants and the Women Writing Culture Seminar.

\section{NOTES}

1. The images of cultivation and weaving are used both deliberately and with caution here. I recognize the danger, suggested by feminist ethnographer Lila AbuLughod, of digressing into an explication of 'poetics' at the expense of the 'politics of ethnography' (Abu-Lughod, 1991:149).

2. See Janet Finn, this issue, for a discussion of Ella Deloria.

3. The mutual influences of ethnography and fiction become even more apparent with Hurston's publication of Their Eyes Were Watching God in 1937.

\section{REFERENCES}

Abu-Lughod, Lila (1991)

'Writing Against Culture', in Richard G. Fox (ed.) Recapturing Anthropology: Working in the Present. Santa Fe: School of American Research Press.

Dorst, John (1987)

'Rereading Mules and Men: Toward the Death of the Ethnographer', Cultural Anthropology 2: 305-318.

Gordon, Deborah (1990)

'The Politics of Ethnographic Authority: Race and Writing in the Ethnography of Margaret Mead and Zora Neale Hurston', in Marc Manganaro (ed.) Modernist Anthropology: From Fieldwork to Text. Princeton: Princeton University Press. Hemenway, Robert (1977)

Zora Neale Hurston: A Literary Biography. Urbana: University of Illinois Press. 
Hemenway, Robert (1990)

'The Personal Dimension in Their Eyes Were Watching God', in Michael Awkward (ed.) New Essays on Their Eyes Were Watching God. Cambridge: Cambridge University Press.

Hurston, Zora Neale (1935)

Mules and Men. New York: Perennial Library (Reprinted 1990, New York: Harper and Row).

Hurston, Zora Neale (1937)

Their Eyes Were Watching God. Philadelphia: J.B. Lippincott (Reprinted 1990, New York: Harper and Row).

Hurston, Zora Neale (1938)

Tell My Horse. New York: J.B. Lippincott (Reprinted 1990, New York: Harper and Row).

Kondo, Dorinne K. (1985)

'Dissolution and Reconstitution of Self: Implications for Anthropological Epistemology', Cultural Anthropology 1: 74-88.

Mikell, Gwendolyn (1983)

'The Anthropological Imagination of Zora Neale Hurston', Westerm Joumal of Black Studies 7(1): 27-35.

Mikell, Gwendolyn (1989)

'Zora Neale Hurston', in Ute Gacs, Aisha Khan, Jerrie McIntyre and Ruth Weinberg (eds) Women Anthropologists: Selected Biographies. Urbana: University of Illinois Press. 